
Theoretical \& Applied Science

p-ISSN: 2308-4944 (print) e-ISSN: 2409-0085 (online)

Komol Usmanov

an independent researcher of the Ethics and aesthetics department, National University of Uzbekistan gulchehra_3@mail.ru

Year: $2016 \quad$ Issue: 9 Volume: 41

Published: $30.09 .2016 \quad$ http://T-Science.org

SECTION 30. Philosophy.

\title{
SOME MORAL FEATURES OF UZBEK PEOPLE'S NATIONAL HERO JALAL AD-DIN MANGUBERDI
}

Abstract: In the article are researched some moral scales of Jalal ad-Din Manguberdi s personal character, who is one of the best-estimated historical figures, one of the founders of patriotic feelings in the moral-historical heritage of Uzbek people. The author shows patriotic feelings of the man, who sacrificed his life for pure faith, patriotism and humanitarianism, purity, knowledge and wisdom, justice and religion, by scientific-historical methods.

Key words: Jalal ad-Din Manguberdi, humanitarianism, patriotism, spiritual heritage, moral values, spirituality, courage, brevity, despotism, occupation, independence.

Language: English

Citation: Usmanov K (2016) SOME MORAL FEATURES OF UZBEK PEOPLE'S NATIONAL HERO JALAL AD-DIN MANGUBERDI. ISJ Theoretical \& Applied Science, 09 (41): 189-192.

Soi: http://s-o-i.org/1.1/TAS-09-41-33 Doi: crossef http://dx.doi.org/10.15863/TAS.2016.09.41.33

\section{Introduction}

Ideal, ideological, scientific, cultural, religious and moral values, world-outlook, traditions, customs and relationships are the youngers' base of spiritual heritage in the society. Cultural values and spiritual heritage have been servicing for the society as the great source of spirituality.

Despite continued strong ideological pressure for a long time, people passed on from generation to generation in their historical and cultural values, and has managed to preserve its own traditions.

The first days of independence created by our ancestors for centuries bring very great, the rich spiritual and cultural heritage of the state policy has become a very important level. Many of the great generals in the history of humanity lived. Alexander the Great, Julius Caesar, Charlemagne, Genghis Khan, Jalal ad-Din Manguberdi, Temur Malik, Amir Temur, Napoleon Bonaparte, Simon Bolivar, as every one of the commanders of the glorious nation, and, in general, have a place in the history of mankind. The above-mentioned commanders were destructive or constructive, fair or unfair policy that vary from one another. Military history does not only researches the role of those rulers, but their military strategies.
Genghis Khan, who conquered about half of the world, was also the first defeat of our common witness to the historical sources.

The thousand-year history of foreign occupation of our Motherland, the evil forces to protect our nation's freedom and honour of the great events in this struggle for the sake of preserving the courage and the courage of the great names over the centuries in his bright memory. National heroes such as Jalal ad-Din Manguberdi, Najm ad-Din Kubra, Amir Temur left an indelible mark on the history of national heroism. One of the heroism is heroism of Jalal ad-Din.

\section{Materials and Methods}

After the Independence, the ruler of Khorezm Jalal ad-Din Manguberdi, who was a patriot skilled commander, has also been servicing as scientific research object. His patriotism based on the very deep and strong ethnic-linguistic and cultural roots.

Jalal ad-Din Manguberdi inherit the broken kingdom. The next ten years in the life of the Khorezm state recovery against the Mongol invaders in the way of glorious, sometimes the fight is full of tragic events. About Manguberdi, his life and struggles were written by historians. Of course, it is the most comprehensive book is Shahab ad-Din alNasavi`s 'Sîrat us-Sultan Jalal ad-Din Manguberdi'. 
In addition, Ota Malik Juwayni, Ibn al-Asir, Juzjoniy, Ibn Bibi, Ibn Vosil and other historians wrote a lot of interesting information about Jalal adDin`s lifetime. And also, there are lots of facts about him in Georgians and Armenians sources. Shahab ad-Din al-Nasavi describes the commander writing: 'He (Jalal ad-Din) was swarthy, medium height, according to his speech he was Turk, but he also spoke Persian'.

He can be said the lion among lions, talented riders in the world. He was gentle nature, never got angry and cursing. He was a very serious man, but lots of uprisings had influenced the nature of the period. He tried to improve the living conditions of citizens, but stresses period, the government had been forced to use violence. 'Help comes only from Allah' was written on his military flags.

Genghis Khan, who had almost never lost in the battles, was seriously concerned by our great ancestor - Jalal ad-Din's unbelievable victories.

Jalal ad-Din`s skill, talent and justice, a high sense of patriotism could be seen in his every battle against the Mongol army. Jalal ad-Din`s these natural characters reflected in their struggle against the yoke of the Genghis Khan and his occupation.

In particular, when Jalal ad-Din attacked to the castle of Valiyon, Genghis Khan sent Takajuk and Malghur, who were one of his major generals of Genghis Khan's troops, to beat Jalal ad-Din. But after a 3-day battle brought them to defeat more than 1,000 Mongolian soldiers were killed, the surviving part of the soldiers went away by jumping the Panjshir River, and they demolished the bridge. That was the first great Jalal ad-Din`s victory against Mongolian invasion. Despite this, Genghis Khan sent Shiki Khutukhu with an army of 45 thousand men to stand against Jalal ad-Din Manguberdi. Victory was Jalal ad-Din Manguberdi`s at the battle near Parvan. The first time in the history of military tactics, Jalal ad-Din stood against the enemy's cavalry on the foot beside a horse. It was one of the military tactic method. The defeat made Genghis Khan, who had not known a serious loss until that time, collect a main part of his army and be a commander upon it on himself.

Genghis Khan gathered a large army to beat Jalal ad-Din. In the battle near the city of Ghardiz, Jalal ad-Din beat the frontier part of Genghis Khan's soldiers. But Jalal ad-Din returned to the Sind river, because of having less soldiers than Genghis Khan`s. Genghis Khan's army surrounded the opportunity to go crossed Jalal ad-Din Manguberdi. The battle, which has been written in gold letters by western historians, between Jalal ad-Din and Genghis Khan`s army began in the morning of November 24, 1221, and lasted for three days. When Ishchi Kutukhu nuyan, one of Genghis Khan's generals, came bowing his head to Genghis Khan`s palace, Genghis collected his army and went to the struggle on himself against Sultan Jalal ad-Din. Jalal ad-Din did not want to begin the battle with Genghis Khan, whose soldiers more by lots of numbers than Jalal ad-Din`s, and went from Ghazni city to the Sind river. Jalal ad-Din made a great effort to prepare boats to swim to another bank, and to return the commanders, who had gone away from Jalal adDin`s troops, when he came to the edge of the river. But the enemy stood against finishing those tasks. Jalal ad-Din started a battle against Mongol soldiers by force. Because he was between the river and Mongolian invaders. Seeing Jalal ad-Din in the difficult position, Genghis Khan ordered to catch him alive.

Sultan felt this bad intentions, Jalal ad-Din chose a way to the Sind river. He jumped into the river by 20 feet height $(6 \mathrm{~m} 10 \mathrm{~cm})$ holding a flag in one hand and a shield in another hand, and swan to the other side. Genghis Khan wanted to pursuit Jalal ad-Din, but he stopped his solders. On November 25, 1221 , Jalal ad-Din swam to the other bank with 4000 his soldiers and went to inner part of the desert. This desert has been called Jalaly till nowadays. According to Mirzo Ulugbek's 'History of the four realms', Genghis Khan said being surprised by Jalal ad-Din`s courage:

Thinking about Jalal ad-Din`s position and his solving to the great problem, Sohibqironi A'zam Chingizkhoni muazzam (The great King of greats Genghiz Khan the great) was really surprised.

Poetry (content):

The great of greats (Genghis Khan) was glad to see Sultan (Jalal ad-Din)'s action. And he said: 'Since the universe was creature, there has not been born a man like Jalal ad-Din. He is like a lion in the wilderness, victorious warrior, a river fish (shark) as courageous. How come, no one will be appreciated, there is no conflict alike. But he taught brevity to be itself. He opened his brave hands in front of fortune (that is to say, he was not afraid of accidents of fortune). There is no escaping from him by brevity. Everything is God's, who is the greatest one, whatever You do or not.

Seeing Jalal ad-Din`s brevity, Sohibqiron (the great king, Genghis Khan) was very shocked, and glorified Jalal ad-Din, and said to himself sons: "Every father needs to the son like him, who can rescue from two accidents: the water and the fire!' Sultan (Jalal ad-Din) has been narrowed lots of stories about his brevity, and every son must learn them!'[3, pp.183-184].

After that Genghis Khan understood perfectly that he was faced the enemy, who was equal with him in power and mind. And Genghis Khan prepared all things to prevent Jalal ad-Din. A few days later, Jalal ad-Din gathered 7 thousands soldiers. In 1220, Genghis Khan sent Turbay Tuqshin and Bola Nuyon with 20 thousand people to Jalal ad-Din. Them approached to the castle of Multan, but they did not 
beat the castle and they could not stand in the hot weather, they returned. Sultan Jalal ad-Din occupied the cities of Dvin and Lori. Leaders of Surmary city agreed to be under Jalal ad-Din`s flag. In September, 1227, Jalal ad-Din won Taynol Nuyon, one of the Mongols' generals, in the village of Sin, which was situated 30 chakirim (about 30-35 miles) far from Isfahan. Later the general said about Sultan Jalal adDin: 'He was real brave man of his modernity, he was leader of all his same-age-people [1, p.112].

About Jalal ad-Din his personal secretary, historian Nasafy writes: "Jalal ad-Din was dark-skin, medium height, according to his speech he was Turkic. And he also knew Persian perfectly. I must write about his courage, that he was the most powerful lion among the powerful lions. He held his words, never held a grudge, and was frank, righteous person. He was a serious person. He never smiled. At the very most, he hardly smiled. He hated injustice. Jalal ad-Din was very confident, very brave, never confused in critical positions, was courageous and brave commander ..." [5, p.11].

Khorezmshah Sultan Jalal ad-Din, whose extraordinary courage and unbreakable will impressed Genghis Khan, according to historian Shahob ad-Din an-Nasafy, was one of the great commanders of his time, the great lion among lions, the most courageous among brave men. He devoted his short, but eventful life`s half to struggle against the plague of the century - Mongolian invasion [5, p.77].

The war against Genghis Khan, which was on the bank of the Sindh river, is very popular among historians, and it has been an object of lots of scientific researches. In particular, according to the British orientalist G. Raverty and Russian scientist and traveler G.E. Grum-Grjimaylo, since Jalal adDin jumped into the river, it has been called Chuli (Juli - desert) Jaloli, which means the desert of Jalal ad-Din. And also, some orientalists, who travelled in Mongolia in the beginning of the XX century, wrote plenty of interesting information. There is mausoleum of Genghis Khan in Edjen Khuru, which is in Inner Mongolia (Inner Mongolia - now the People's Republic of China). There is held lots of ceremonies devoted Genghis Khan`s spirit. At first, they mention Genghis Khan`s victory against Jalal ad-Din, and they pray to the divine forces for receiving it [6].

At the 800 anniversary ceremony of Jalal adDin the President of the Republic of Uzbekistan Islam Karimov estimated Sultan`s courage, patriotism highly. According to the President, Jalal ad-Din is not only Khorezm's pride, but he is the pride of Uzbekistan, he is the symbol of patriotism, which helps stand against to evil invaders, he is an evidence, that proves our might which beats enemies' wrath. The brevity and courage of this patriot man give us full rights to live proud. The
President of Uzbekistan Islam Karimov said: 'The man who unites people under one flag, who thinks about his country`s future, who estimates others` good intention as own ambition, who can protect his own nation from evil forces, may trace indelible mark in the history. That is true.

Jalal ad-Din Manguberdi is a symbol of such courage and exemplary figures.

Sultan Jalal ad-Din teaches us to love blue sky and peace life of our country, to protect our descendants, who replace our social position in life, and lots of meritorious actions [2].

In 1998, the Uzbek government adopted the order 'About celebration of Jalal ad-Din's 800 anniversary of birth' to immortalize his memory and to respect his spirit because of his courage in the battle against Mongolian invaders and his patriotism. According to the order, a statue of Jalal ad-Din was made in Khorezm, a lot of highways, squares, public enterprises and others named after him. A historian Nasafy, who spent all his life with Jalal ad-Din, dedicated to him his work, which is named 'Siyrat as-Sultan Jalal ad-Din Manguberdi' (History of Sultan Jalal ad-Din), Maksud Sheikhzade, popular Uzbek-Azerbaijanian writer, wrote a play 'Jalal adDin' (1943). Plenty of documentary films, epics, plays, which were dedicated to Jalal ad-Din, have been made. On August 30, 2000, the Order 'Jalal adDin Manguberdi' was established [4, p.538].

Being successful in reforms and restoration of spiritual heritage is the important element in development of the country. As you know, over the centuries the people of high spirituality, justice, education such noble qualities developed in close coordination with the teachings of Eastern philosophy and religion. In turn, these philosophical and moral teachings enriched from the genius of our people.

\section{Conclusion}

Today our military patriotism, which is main part of our spirituality, should be developed according to these philosophy and moral courage of our ancestors.

Taking into account the views expressed above can provide the following summary:

First, the phenomenon of the spiritual heritage of the Uzbek people, national heroes, and there are many people who collect samples of military patriotism. Because, since the beginning our people have been trying to deserve to the divine power, which is in their vein, have been bringing their sons up as brave, honest, courage men.

Secondly, it can be said according to historical facts, brevity is not the feature, which can be seen at everyone's character, but it requests a specific readiness, in which man can give even his life for developing his country. 


\begin{tabular}{l|lrl|l|ll} 
& ISRA (India) & $=\mathbf{1 . 3 4 4}$ & SIS (USA) & $=\mathbf{0 . 9 1 2}$ & ICV (Poland) & $=\mathbf{6 . 6 3 0}$ \\
Impact Factor: & ISI (Dubai, UAE) $=\mathbf{0 . 8 2 9}$ & PUHL (Russia) $=\mathbf{0 . 2 3 4}$ & PIF (India) & $=\mathbf{1 . 9 4 0}$ \\
& GIF (Australia) & $\mathbf{0 . 5 6 4}$ & ESJI (KZ) & $=\mathbf{1 . 0 4 2}$ & IBI (India) & $=\mathbf{4 . 2 6 0}$ \\
& JIF & $\mathbf{1 . 5 0 0}$ & SJIF (Morocco) & $=\mathbf{2 . 0 3 1}$ & & \\
\hline
\end{tabular}

\section{References:}

1. Buniyotov Z (1999) Anushtegin Xorazmshokhlar davlati (1097-1231).

Toshkent: A.Qodiriy nomidagi nashriyot, 1999.

2. Karimov I (1999) Speech at the 800 anniversary ceremony of Jalal ad-Din`s birthday. 5 November, 1999.

3. Mirzo Ulugbek (1994) Tort ulus tarixi. Toshkent: Cholpon nashriyoti, 1994.
4. (2002) National Encyplopeadia of Uzbekistan in 12 volumes. Vol. 3. - Tashkent: O'zbekiston milliy ensiklopediyasi, 2002.

5. Shaxobiddin Muxammad al-Nasaviy (1999) Sulton Jaloliddin Manguberdi tafsiloti. Toshkent: Ma'naviyat, 1999.

6. Toshev Nuryog'di (2016) Vatanparvar gazetasi. 